\title{
Impact and Perceived Constraints in Adoption of Climate Resilient Technologies in Flood Prone Areas of West Bengal, India
}

\author{
Debjyoti Majumder, Rakesh Roy*, Paramita Bhowmik, Bankim Chandra Rudra, \\ Adwaita Mondal, Bhabani Das and Samima Sultana
}

Malda KrishiVigyan Kendra, Uttar Banga Krishi Viswavidyalaya, Ratua, Malda-732205

*Corresponding author

Keywords

$\mathrm{BC}$ ratio,

Constraints, Flood,

Malda, NICRA,

Technologies

Article Info

Accepted:

07 March 2020

Available Online:

10 April 2020

\begin{abstract}
A B S T R A C T
Malda KVK has started it activities on NICRA (National Innovations on Climate Resilient Agriculture) from 2010-11. Under Manikchak block, 6 villages were purposively selected for implementation of the NICRA project based on the effect of flood in the area. A study was undertaken to assess the impact of different climate resilient technologies based on production, income and $\mathrm{BC}$ ratio. Perceived constraints were also assessed in implementation of these climate resilient technologies by the farmers in adopted villages in terms of technical constraints, economic constraints, storage and marketing constraints and general constraints. The study shows that all the major climate resilient technologies have considerable impact in the livelihood of the farmers in flood affected NICRA adopted villages. Constraints perceived by the farmers were high disease incidence of plants and animal in respect to technical constraints. Lack of credit facility in the area was the major constraints perceived by the farmers in respect to economic constraints. Lack of cooperative marketing system was the major constraints perceived by the farmers in respect to storage and marketing constraints and unavailability of agricultural labour was the major constraints perceived by the farmers in respect to general constraints. It is still early to predict the impact of these climate resilient technologies to their livelihood but the impact of these technologies might be more visible if we can minimize the constraints perceived by the farmers.
\end{abstract}

\section{Introduction}

Increasing climatic variability and changes in climate are likely to exaggerate the problems of future food security by exerting pressure on agriculture. Developing countries such as India are more vulnerable, as its high population depends on agriculture which creates excessive pressure on natural resources and un-utilization of available coping mechanisms. As a response to these challenges, both farmers as well as research community developed an extensive range of agricultural practices which could augment farming systems' resiliency to climate change (Wezel et al., 2014). 
Research on the impact of climate change and vulnerability on agriculture is a high priority in India. Developing the ability to confidently estimate the impacts of climate change on agriculture is critically important (Khan et al., 2009). Looking into the concerns, Indian Council of Agricultural Research initiated the National Innovation for Climate Resilient Agriculture (NICRA) across the country in collaboration with ICAR research institutes, SAUs and KVKs. The project is implemented in 100 districts involving over one lakh farm families across the country.

This project was also implemented by Malda Krishi Vigyan Kendra, Uttar Banga Krishi Viswavidyalaya from the year 2011. Various modules implemented under Technology Demonstration Component (TDC) viz. natural resource management, crop management, livestock and fisheries and institutional interventions which deal with adaptation of crop and livestock production systems to climate variability.

Through NICRA project, Malda KVK has demonstrated and encouraged to adopt a wide-ranging technologies and improved practices for mitigating climate change to provoke farming as business. This study was undertaken to assess the impact of different spheres of technological interventions and associated constraints in implementation of these technologies in the project area.

\section{Materials and Methods}

The village of Malda district represent old alluvial agro ecosystem and mostly affected by flood, storm and high intensity \& erratic rainfall. The project site was Brojolaltola, Mahendratola, Meherchandtola, Jairamtola, Mahendratola colony and Deherutola villages of Manikchak block of Malda district of West Bengal to address the flood vulnerability. The project site under NICRA project were purposively selected to assess the impact of technologies under NICRA and constraints perceived to implement these technologies. To do the study, ex-post-facto research design was used. In this regard, before and after comparisons on various variables were obtained with the help of baseline data and recall memories of respondents. The data collection was done on the interventions implemented by the KVK under NICRA. Impact of the interventions was studied and values of before and after the interventions were compared and tested with suitable test statistics appropriate for the intervention.

The benefit-cost ratio indicates the relationship between the cost and benefit of project or investment for analysis as it is shown by the present value of benefit expected divided by present value of cost which helps to determine the viability and value that can be derived from investment or project.

Benefit Cost Ratio $(\mathrm{BCR})=$ Present Value (PV) of Benefit Expected from the Project / Present Value (PV) of the Cost of the Project

If that investment or the project has a BCR value that is greater than 1 than the project can be expected to return or deliver a positive NPV i.e. net present value to the business or the firm and their investors. If BCR value is less than 1, then the project cost can be expected to be higher than the returns and therefore, it should be discarded. The respective cost benefit ratio under different technological interventions were calculated based on sampling data under NICRA project which was calculated as per the above mentioned formula.

Constraints in adoption of different climate resilient technologies was measured by Henry Garrett Ranking Method. Garrett ranking technique (Garrett, 1981) was adopted to find 
constraints in adoption of Climate Resilient Technologies. The respondents were asked to rank the factors given. The orders of merit, assigned by the respondents were converted into ranks by using the following formula. Percent Position of Each Rank = $100(\mathrm{Rij}$ $0.5) / \mathrm{Nj}$

$\mathrm{R}=$ Rank given for $\mathrm{i}^{\text {th }}$ factor by $\mathrm{j}^{\text {th }}$ individual $\mathrm{N}=$ Number of factors ranked by $\mathrm{j}^{\text {th }}$ individual

The percentage position of each rank thus obtained is converted into scores by referring to the table 1 given by Henry Garrett. Then for each factor the scores of individual respondents were added together and divided by the total number of respondents for whom the scores were added. These mean scores (MS) for all the factors were arranged in order of ranks and inference was drawn.

\section{Results and Discussion}

Impact of different climate resilient technologies in NICRA adopted village

Malda KVK had demonstrated various climate resilient technologies in NICRA adopted village to address the climatic vulnerability of the district. The various technologies demonstrated by the KVK and its impact on technological and socio economic aspect.

\section{Impact in production and income through multi-tier horticulture}

The multi-tier horticultural practices were one of the most promising techniques to cope up with flooding and utilizing the submerged land to generate extra farm income among the household of the NICRA adapted village. The adopted technologies resulted in gradual increase in farm production and year round income generation. The studies showed that with adoption of the practices, the production level enhanced by about 41 per cent (Table 2) and farm income by one third folds and subsequently enhance the BC ratio to 2.10 . Multitier horticulture proved to be an efficient alternative for generating permanent income year round.

\section{Impact in production and income through zero tillage practices}

Zero tillage initiative was undertaken under NICRA project with a vision of natural resources management. Survey studies revealed that maize cultivation by zero tillage incurred significant higher income as well as enhance the productivity both under check as well as demonstration practices, The productivity was significantly increased to 25 per cent higher over conventional practices and income was found to be 30 per cent higher with a $\mathrm{BC}$ ratio of 2.44 . The higher $\mathrm{BC}$ ratio was found due to lower cost incurred towards land preparation, labour cost and lesser irrigation. Similar, type of results was also obtained in case of zero tilled wheat cultivation where productivity increased by 15 per cent with $\mathrm{BC}$ ratio of 2.41 (Table 3 ). It is noteworthy to suggested that rice(short duration)-wheat-mung (by Zero Tillage method) can be recommended as new cropping system for long term sustainability and profit.

\section{Impact in production and income through composite fish culture}

The areas under NICRA project is inundated with water during monsoon and post monsoon season. The low lying areas become unproductive during the post monsoon season where no alternative crop could be taken. Nearly, five or six different species are grown together in a single fish pond. The survival rate of fish increases and their yield also increases without affecting the other species. 
These unutilized areas were targeted and focused to introduce low cost composite fish culture with an aim to enhance area and utilize unproductive area through carp composite culture where compatible carp species of Indian major carps (Catla, rohu, mrigal) and exotic carps (grass carp, silver carp) were distributed. It was observed that the production after bringing area under NICRA increased by 125 per cent and income was increased radically by around 2.05 lakhs having a $\mathrm{BC}$ ratio of 2.45 .

It is well understood that location specific and resource based fish farming can be an important avenues for improving livelihood and income for mainly marginal and poor farmers. Fish farming varies from one area to another in terms of production combination, rates and sizes. Fish farming has a great capacity of making more food available thus enhancing food security and creating more jobs for the unemployed masses in the region (Table 4).

\section{Impact in production and income through nutrition garden}

Primary objective of this technological intervention was to develop nutrition garden model especially for rural households of vulnerable areas which will ensure healthy diet that contains adequate quantities of vitamins and macro and micro-nutrients by producing diverse kinds of vegetables and spices viz. cabbage, cauliflower, amaranthus, brinjal, chilli, turmeric, Brocolli etc (Table 5).

The high bund areas along the Ganges being highly fertile was intervened by the scientists of the KVK to encourage production of high value nutritional crops. It was observed that after interventions the production of nutritional crops enhanced significantly by almost 48.5 per cent and income generation also increased. The $\mathrm{BC}$ ratio after intervention was found to be around 2.63 from which it can concluded that it has a huge scope under NICRA adapted areas for revenue generation as well as overall improvement of the health.

\section{Impact in production and income through mushroom cultivation}

Mushroom cultivation is a technology where women can play a pivotal role and contribute to generate additional income. It was observed that many unutilized space in the backyards of the local households were unutilized where small scale mushroom production could be undertaken. In this regard after proper scientific training and technological demonstrations the women's were supplied with spawns and the result was found to be promising. After interventions the production was found to be increased by about by 40 per cent generating about Rs. 14500 with a BCR ratio of 1.42 (Table 6). Cultivation of edible mushrooms is one of the most economically viable processes for the bioconversion of lingo-cellulosic wastes (Bano et al., 1979).

\section{Impact in production and income through production of vermi-compost}

Vermicomposting is a process of artificial rearing of earthworms and the process of using them for converting the degradable/semi-degradable biomass into a simpler waste soluble substance rich in nutrients, beneficial soil micro flora and has the properties of inhabiting pathogenic microbes.

Total 7 vermicompost units were demonstrated covering 16 ha of area in orchard, cereal crops and vegetable cultivation in 54 farmers field with average net return of 18,440/unit/year with $\mathrm{B}: \mathrm{C}$ ratio of 2.21 (Table 7). Even in low flood prone area, it was observed that it has contributed 
highly in improving the soil fertility status (VC:N-2.0\%， P2O5-5.2\%， K2O-0.88\%) making the method cost effective and farmers friendly.

\section{Impact in production and income through mulching}

Rice based cropping system during kharif season due to inundated water logging results in cultivation of vegetables in the upland slopes after the water recedes back. Interventions were made to utilize Kharif paddy straw mulch after their harvest and use it as mulch to check weed growth and conserve the surplus moisture within the soil itself. Significant reduction in weed management as well as irrigation cost was found through this technology.

Also, productivity was significantly enhanced incase of both cauliflower and cabbage which was found to be $190 \mathrm{q} / \mathrm{ha}$ and $210 \mathrm{q} / \mathrm{ha}$ respectively. Higher B:C ratio both in case of cauliflower and cabbage cultivation practices suggests that the technology is highly efficient for conserving residual moisture in high value crops and can be used specially during Rabi seasons (Table 8).

\section{Impact in production and income through seed and soil treatment to check root rot and stem rot}

Due to inundated water logging situation especially during rainy season, the excess moisture in soil inhibits the growth and development of vegetables grown in this areas due to stem rot and root rot problem caused by fungal pathogens. To curb these diseases and reduce the cost of production by unnecessary sprayings of chemicals as curative measures, proper seed and soil treatment as a preventive measure is very essential. The technology of seed treatment for brinjal and nodes of pointed gourd were advised with carbendazim 50\% WP @ 2g/kg of seed and the soil treatment with Trichoderma viridae @ $1.5 \mathrm{~kg} / \mathrm{ha}$ and Pseudomonas fluorescence @ 1.5kg/ha along with $50 \mathrm{~kg}$ cow dung manure.

The higher productivity and $\mathrm{B}$ : $\mathrm{C}$ ratio was found in case of both brinjal and pointed gourd which was found to be $309.14 \mathrm{q} / \mathrm{ha}$ and $3.55 ; 9.45 \mathrm{q} / \mathrm{ha}$ and 2.80 respectively. The per cent increase of yield after implementation of the technology was $21.44 \%$ and $62.54 \%$ in brinjal and pointed gourd, respectively. It reveals that the technology is highly efficient for protecting vegetables from root and stem rot due to high conserved moisture condition in soil after Kharif seasons (Table 9).

Impact in production and income through use of different attractants or traps for vegetables

Yellow sticky traps and Delta traps are ecofriendly approach and environmentally safe innovative technologies which reduce the cost of cultivation by unnecessary sprayings against white fly without having any particular idea about the incidence, nature and exact time of infestation by white fly and fruit and shoot borer in brinjal and melon fruit fly in cucurbitaceous vegetables. These technologies also reduce the risk of rotting problem of vegetables after rainy season due to excessive use of insecticides in excess moisture condition. Whitefly causes direct damage, indirect damage and virus transmission by leaf chlorosis, leaf withering, reducing the plant growth rate and yield and premature dropping of leaves that eventually results in plant death. It also reduces the photosynthesis and lessens the value of the plant or yields rendering them unmarketable. Implementation of yellow sticky trap was done in 6.5 ha area among 24 farmers. This technology has enhanced the yield to $22.86 \%$ and $\mathrm{BC}$ ratio was 3.72 (Table 10). 
Implementation of Delta traps against brinjal fruit and shoot borer enhanced yield (519.28 $\mathrm{q} / \mathrm{ha}$ ) and $\mathrm{BC}$ ratio of 2.97 (Table 10). The per cent yield increase after implementing the technology was $26.21 \%$. It is very much difficult to manage melon fruit fly in cucurbits simply through the application of chemical pesticides due to their peculiar biological features. The farmers show little concern for the residual effect of chemicals, being more concerned about profit.

\section{Impact in production and income through use of traps for orchard crops (Mango)}

One of the major constraints of mango production and export along with quality as well as quantity is mango fruit fly, Bactrocera dorsalis. The percentage of infestation of this pest varies from 20-30\% in Fazli, 25-35\% in Lakshmanbhog, $10 \%$ in Aswina and 5\% in Mohanbhog variety of mango. Due to cryptic nature of fly larvae, they mostly remain unaffected by insecticides and the chances of insecticide residues in fruits also increase.

Methyl eugenol has both olfactory as well as phago-stimulatory action and is known to attract male fruit flies from a distance of 800 $\mathrm{m}$. Keeping this in view this technology has been selected for wide spread dissemination in NICRA villages i.e. management of fruit flies through mass trapping with methyl eugenol in mango orchards so as to increase the productivity as well as quality and quantity of mango for export.

By adopting this technology, the incidence is reduced from $30-35 \%$ to $5-10 \%$ and $59.51 \%$ yield was increased than the traditional method of treatment for mango fruit fly. This technology was initially conducted with 10 farmers and 2.4 ha areas. This technology increases yield of mango $18.40 \%$ than previous years' production and also higher $\mathrm{BC}$ ratio was found 1.66 after adopting this technology. It is an eco-friendly approach and environmentally safe innovative technology which reduce the cost of cultivation of mango by unnecessary sprayings against fruit fly without having any particular idea about the incidence, nature and exact time of infestation by fruit fly. The result indicates that the technology is highly efficient for protecting mango from fruit fly (Table 11).

\section{Perceived constraints in adoption of climate resilient technologies in NICRA adopted village}

A new adaptation of technologies has always been accompanied with several lacunas. The constraints in adoption of technologies were measured by Garret ranking method. The constraints were basically classified into four subcategories based on technological interventions, economics, storage and marketing and general constraints. The sampling was randomly done amongst the farm holders in the specified areas and based upon mean score the ranking was done.

Based on the survey the main technological constraint was found to be incident of pest and diseases in the crops as well as livestock. Flood water inundation and lower elevation may be one of the basic reasons behind severity of disease incidence. Lack of technical knowledge was foremost reason behind it which has been given rank based on scoring (Table 12).

While, availability of fodder was found to be the least constraint among all the technical constraints, as the region is well supplied with natural green and grass fodder. The survey also gave us an idea of the economic constraints which is observed in table. Lack of credit facilities in the region and high labour cost was the main benevolent factor beyond such lagging growth before the interventions by the Malda KVK. 
Table.1 Showing Garret's Table Value for different rank orders

\begin{tabular}{|c|c|c|c|}
\hline Rank & \multicolumn{2}{|c|}{ Percentage Position } & Garrett's Table Value \\
\hline $\mathbf{1}$ & $100(1-0.5) / 7$ & $=7.14$ & 79 \\
\hline $\mathbf{2}$ & $100(2-0.5) / 7$ & $=21.49$ & 66 \\
\hline $\mathbf{3}$ & $100(3-0.5) / 7$ & $=35.71$ & 58 \\
\hline $\mathbf{4}$ & $100(4-0.5) / 7$ & $=50.00$ & 50 \\
\hline $\mathbf{5}$ & $100(5-0.5) / 7$ & $=64.29$ & 43 \\
\hline $\mathbf{6}$ & $100(6-0.5) / 7$ & $=78.57$ & 35 \\
\hline $\mathbf{7}$ & $100(7-0.5) / 7$ & $=92.86$ & 22 \\
\hline
\end{tabular}

Table.2 Impact in production and income through Multi-Tier Horticulture

\begin{tabular}{|l|c|c|c|c|c|c|}
\hline \multirow{2}{*}{ Technology } & \multicolumn{2}{|c|}{ Production (t/ha) } & \multicolumn{2}{c|}{ Income (Rs.) } & \multicolumn{2}{c|}{ BCR } \\
\cline { 2 - 7 } & Before & After & Before & After & Before & After \\
\hline Multi-Tier Horticulture & 5.2 & 8.8 & 3.2 lakhs & 4.8 lakhs & 1.32 & 2.10 \\
\hline
\end{tabular}

Table. 3 Impact in production and income through zero tillage practices

\begin{tabular}{|l|c|c|c|c|c|c|c|}
\hline \multirow{2}{*}{ Technology } & \multirow{2}{*}{ Crop } & \multicolumn{2}{|c|}{ Production (t/ha) } & \multicolumn{2}{|c|}{ Income (Rs.) } & \multicolumn{2}{c|}{ BCR } \\
\cline { 3 - 8 } & & Before & After & Before & After & Before & After \\
\hline \multirow{2}{*}{ Zero tillage } & Maize & 7.5 & 10.0 & 0.91 lakhs & 1.30 lakhs & 1.71 & 2.44 \\
\cline { 2 - 8 } & Wheat & 3.5 & 4.1 & 0.51 lakhs & 1.06 lakhs & 1.80 & 2.41 \\
\hline
\end{tabular}

Table.4 Impact in production and income through composite fish culture

\begin{tabular}{|c|c|c|c|c|c|c|}
\hline \multirow{2}{*}{ Technology } & \multicolumn{2}{|c|}{ Production (qtl./ha) } & \multicolumn{2}{c|}{ Income (Rs.) } & \multicolumn{2}{c|}{ BCR } \\
\cline { 2 - 7 } & Before & After & Before & After & Before & After \\
\hline Composite fish culture & 11.50 & 23.50 & 1.15 lakhs & 2.05 lakhs & 1.3 & 2.45 \\
\hline
\end{tabular}

Table.5 Impact in production and income through nutrition garden

\begin{tabular}{|c|c|c|c|c|c|c|}
\hline \multirow{2}{*}{ Technology } & \multicolumn{2}{|c|}{ Production (t/ha) } & \multicolumn{2}{c|}{ Income (Rs.) } & \multicolumn{2}{c|}{ BCR } \\
\cline { 2 - 7 } & Before & After & Before & After & Before & After \\
\hline Nutrition garden & 3.5 & 6.8 & 2.25 lakhs & 3.46 lakhs & 1.88 & 2.63 \\
\hline
\end{tabular}

Table.6 Impact in production and income through mushroom cultivation

\begin{tabular}{|c|c|c|c|c|c|c|}
\hline \multirow{2}{*}{ Technology } & \multicolumn{2}{|c|}{ Production (kg) } & \multicolumn{2}{c|}{ Income (Rs.) } & \multicolumn{2}{c|}{ BCR } \\
\cline { 2 - 7 } & Before & After & Before & After & Before & After \\
\hline Mushroom cultivation & 90 & 150 & 8000 & 14500 & 1.22 & 1.42 \\
\hline
\end{tabular}


Table.7 Impact in production and income through production of vermi-compost

\begin{tabular}{|c|c|c|c|c|c|c|}
\hline \multirow{2}{*}{ Technology } & \multicolumn{2}{|c|}{ Production (ton) } & \multicolumn{2}{|c|}{ Income (Rs.) } & \multicolumn{2}{c|}{ BCR } \\
\cline { 2 - 7 } & Before & After & Before & After & Before & After \\
\hline Vermi-compost & 0.0 & 2.0 /harvest & 0.0 & 18,440 & 0.0 & 2.21 \\
& & & & & & \\
\hline
\end{tabular}

Table.8 Impact in production and income through mulching

\begin{tabular}{|c|c|c|c|c|c|c|c|}
\hline \multirow{2}{*}{ Technology } & Crop & \multicolumn{2}{|c|}{ Production (q/ha) } & \multicolumn{2}{|c|}{ Income (Rs.) } & \multicolumn{2}{c|}{ BCR } \\
\cline { 3 - 8 } & & Before & After & Before & After & Before & After \\
\hline \multirow{2}{*}{$\begin{array}{c}\text { Organic } \\
\text { mulching }\end{array}$} & Cauliflower & 166.1 & 190 & 2.25 lakhs & 3.0 lakhs & 1.45 & 2.18 \\
\cline { 2 - 8 } & Cabbage & 180.1 & 210 & 2.35 lakhs & 3.5 lakhs & 1.41 & 2.30 \\
\hline
\end{tabular}

Table.9 Impact in production and income through seed and soil treatment

\begin{tabular}{|c|c|c|c|c|c|c|c|}
\hline Technology & Crop & \multicolumn{2}{|c|}{$\begin{array}{c}\text { Production } \\
\text { Kg/ha }\end{array}$} & \multicolumn{2}{c|}{ Income (Rs.) } & \multicolumn{2}{c|}{ BCR } \\
\cline { 3 - 9 } & Before & After & Before & After & Before & After \\
\hline $\begin{array}{c}\text { Seed and soil } \\
\text { treatment }\end{array}$ & Brinjal & 242.83 & 309.14 & $\begin{array}{c}14.57 \\
\text { lakhs }\end{array}$ & 18.55 lakhs & 2.02 & 3.55 \\
\cline { 2 - 9 } & $\begin{array}{c}\text { Pointed } \\
\text { gourd }\end{array}$ & 3.54 & 9.45 & 0.18 lakhs & 0.48 lakhs & 1.07 & 2.80 \\
\hline
\end{tabular}

Table.10 Impact in production and income through use of different attractants or traps

\begin{tabular}{|c|c|c|c|c|c|c|c|c|}
\hline Technology & Crop & \multicolumn{2}{|c|}{ Production (q/ha) } & \multicolumn{2}{|c|}{ Income (Rs.) } & \multicolumn{2}{|c|}{ BCR } \\
\cline { 3 - 8 } & & Before & After & Before & After & Before & After \\
\hline $\begin{array}{c}\text { Yellow Sticky } \\
\text { traps }\end{array}$ & Brinjal & 243.34 & 297.01 & 2.91 lakhs & 3.5 lakhs & 2.50 & 3.72 \\
\hline Delta traps & Brinjal & 411.45 & 519.28 & 2.89 lakhs & 3.63 lakhs & 1.96 & 2.97 \\
\hline
\end{tabular}

Table.11 Impact in production and income through use of traps for orchard crops

\begin{tabular}{|c|c|c|c|c|c|c|c|}
\hline Technology & Crop & \multicolumn{2}{|c|}{ Production (q/ha) } & \multicolumn{2}{|c|}{ Income (Rs.) } & \multicolumn{2}{|c|}{ BCR } \\
\cline { 3 - 8 } & & Before & After & Before & After & Before & After \\
\hline $\begin{array}{c}\text { Pheromone } \\
\text { traps } \\
\text { (Methyl } \\
\text { eugenol) }\end{array}$ & Mango & 236.63 & 289.99 & 5.50 lakhs & 6.89 lakhs & 0.99 & 1.66 \\
\hline
\end{tabular}


Table.12 Perceived constraints in adoption of climate resilient technologies

\begin{tabular}{|c|c|c|c|c|}
\hline $\begin{array}{l}\text { SI. } \\
\text { No. }\end{array}$ & Constraints & Score & $\begin{array}{l}\text { Mean } \\
\text { Score }\end{array}$ & Rank \\
\hline A & Technical constraints & & & \\
\hline 1. & High diseases incidence in plant and animal & 5018 & 62.73 & I \\
\hline 2. & Lack of technical knowledge & 4183 & 52.29 & II \\
\hline 3. & Low productivity of crop and animal & 4054 & 50.68 & III \\
\hline 4. & Unsuitable soil for agriculture & 3649 & 45.61 & VII \\
\hline 5. & Lack of technical knowledge at right time & 3872 & 48.40 & IV \\
\hline 6. & Poor availability of veterinary service & 3741 & 46.76 & V \\
\hline 7. & Low availability of fodder & 3723 & 46.54 & VI \\
\hline B & Economic constraints & & & \\
\hline 1. & Lack of credit facility in the area & 4992 & 62.40 & I \\
\hline 2. & Costly labour & 4215 & 52.69 & II \\
\hline 3. & High cost of insecticide and pesticides & 3992 & 49.90 & IV \\
\hline 4. & High cost of transportation for marketing of product & 3763 & 47.04 & V \\
\hline 5. & Labour intensive affairs & 4016 & 50.20 & III \\
\hline 6. & High cost of fertilizer & 3653 & 45.66 & VI \\
\hline 7. & High cost of animal feed & 3609 & 45.11 & VII \\
\hline C & Storage and marketing constraints & & & \\
\hline 1. & Lack of co-operative marketing system & 4979 & 62.24 & I \\
\hline 2. & No preservation industry & 4184 & 52.30 & II \\
\hline 3. & Low purchasing power of the consumer & 4054 & 50.68 & III \\
\hline 4. & Lack of storage facility & 3649 & 45.61 & VI \\
\hline 5. & Lack of proper market & 3727 & 46.59 & VII \\
\hline 6. & High fluctuation in market prices & 3741 & 46.76 & $\mathrm{~V}$ \\
\hline 7. & Distant market & 3906 & 48.83 & IV \\
\hline D & General constraints & & & \\
\hline 1. & Unavailability of agricultural labour & 5053 & 63.16 & I \\
\hline 2. & Threat from wild and stray animal & 3877 & 48.46 & V \\
\hline 3. & Poor quality soil & 4000 & 50.00 & III \\
\hline 4. & Small land holding & 3727 & 46.59 & VI \\
\hline 5. & Chances of theft & 3899 & 48.74 & IV \\
\hline 6. & Lack of regular water supply for irrigation & 4004 & 50.05 & II \\
\hline 7. & Reluctance in agriculture & 3680 & 46.00 & VII \\
\hline
\end{tabular}

Similarly, lack of cooperative market chains in the areas and lack of proper storage of perishable vegetables and no preservation industries in the district have compelled them either to choose non-perishable crops or to force sell their products at low cost in nearby panchayat level rural markets. Interestingly, it was found during the survey study that only a small proportion of the populations showed lack of interest in agriculture as a general constraint and hence, was given the least ranking based on scoring (3680) with a mean core of 46.0. Roy et al., (2018) reported that lack of credit facility was the major financial 
constraints in adoption of Darjeeling mandarin orange.

The study shows that the climate resilient technology had positive significant impact on the production and economic aspect in agricultural production in the villages adopted under NICRA project. Proper technology demonstration and dissemination along with changing the psychological mindset among the rural youths and progressive famers considerably improves the economics and farming innovations over the place. Time has come to disseminate these technologies to other adjoining villages for higher adoption of these technologies for higher impact in production and economic gain.

\section{Acknowledgement}

Authors are highly thankful to Director, Central Research Institute for Dryland Agriculture, Hyderabad and Director, ICARATARI Kolkata for providing necessary fund under NICRA project. Authors are also highly thankful to Director of Extension Education, Uttar Banga Krishi Viswavidylaya, Pundibari, Coochbehar for all the infrastructural support.

\section{References}

Bano, Z., Rajarathnam, S. and Nagaraja, N. (1979). Some aspects on the cultivation of Pleurotus flabellatus in India. Mushroom Science, 10(2), 597-608.

Garrett, H.E. (1981). Statistics in Psychology and Education. Published by Vakils, Feffer and Simons Ltd., Mumbai.

Khan, S.A., Kumar, S., Hussain, M.Z. and Kalra, N. (2009). Climate change, climate variability and Indian agriculture- impacts vulnerability and adaptation strategies http:// www.springer.com/978-3-540- 88245-9 Accessed 16 October, 2019.

Roy, R., Kharga, B.D. and Moktan, M.W. (2018). Darjeeling mandarin orange: reasons for its decline and perceived constraints.

Int.J.Curr.Microbiol.App.Sci., 7(9): 1420

Wezel, A., Casagrande, M., Celette, F., Vian, J.F., Ferrer, A. and Peigne, J. (2014). Agroecological practices for sustainable agriculture- a review. Agronomical Sustainable Development, 34:1-20.

\section{How to cite this article:}

Debjyoti Majumder, Rakesh Roy, Paramita Bhowmik, Bankim Chandra Rudra, Adwaita Mondal, Bhabani Das and Samima Sultana. 2020. Impact and Perceived Constraints in Adoption of Climate Resilient Technologies in Flood Prone Areas of West Bengal, India. Int.J.Curr.Microbiol.App.Sci. 9(04): 797-806. doi: https://doi.org/10.20546/ijcmas.2020.904.095 